\title{
Biostratigraphy and paleoenvironment of the Sarmatian (s. l.) deposits from the eastern part of the Moldavian Platform (Comarna borehole) based on foraminifera
}

\section{Bogdan-Adrian Ispas}

Alexandru Ioan Cuza University,

11, Carol I Boulevard 700506,

Iași, Romania

\begin{abstract}
Due to the change of the Paratethys' marine regime with normal salinity to the brackish regime, the Moldavian Platform deposits of this time period are characterized by euryhaline microfaunal forms. Foraminifera species Lobatula lobatula (W. et J.) (Cibicides lobatulus W. et J.), Cycloforina karreri ovata (Serova) (Quinqueloculina karreri ovata Serova), Cycloforina fluviata (Vengl.) (Q. fluviata Vengl.) mark the beginning of the Sarmatian period in the Moldavian Platform; the presence of other genera, like Nonion, Elphidium, Articulina indicate that part of the Upper Badenian specific microfauna adapted to lower salinity water of the Paratethys. Having a small size, the Cibicides genus, marks the sudden change in the environmental conditions and the installation of the brackish regime. The predominance of benthic foraminifera forms indicates a normal oxygen content at the substrate surface, and the abundance of foraminifera species with calcareous tests indicates that the sedimentation of the Lower Sarmatian deposits was made in warm sea conditions.
\end{abstract}

Keywords: foraminifera, biostratigraphy, paleoecology, Sarmatian (s.l.), Miocene, Moldavian Platform

\section{INTRODUCTION}

This study is based on the micropaleontological researches performed in the Sarmatian (s.l.) deposits from the Eastern Moldavian Platform, at the level of Buglovian (Darabani-Mitoc Clays), Volhynian (Darabani-Mitoc Clays) and Lower Bessarabian (Clays with Cryptomactra) of a drilling executed in Comarna locality (Fig. 1).

\footnotetext{
*Corresponding author. Email: bogdan.ispas@student.uaic.ro
}

The drilling from Comarna has been studied by various authors in several papers. Grasu et al. (2002) reported on the core samples of this drilling the Volhynian/Bessarabian limit at 230 metres deep, Brânzilă (2004) identified foraminiferal fauna composed mainly of elphidiids, nonionids and miliolids in the Bessarabian deposits, Brânzilă and Țabară (2005) also, identified a content of palynomorphs in the lower Bessarabian deposits of the Moldovian Platform intercepted by this drilling, while Țabară and Chirilă (2012a, b) made paleoclimatic estimations based on this microfloral content. 


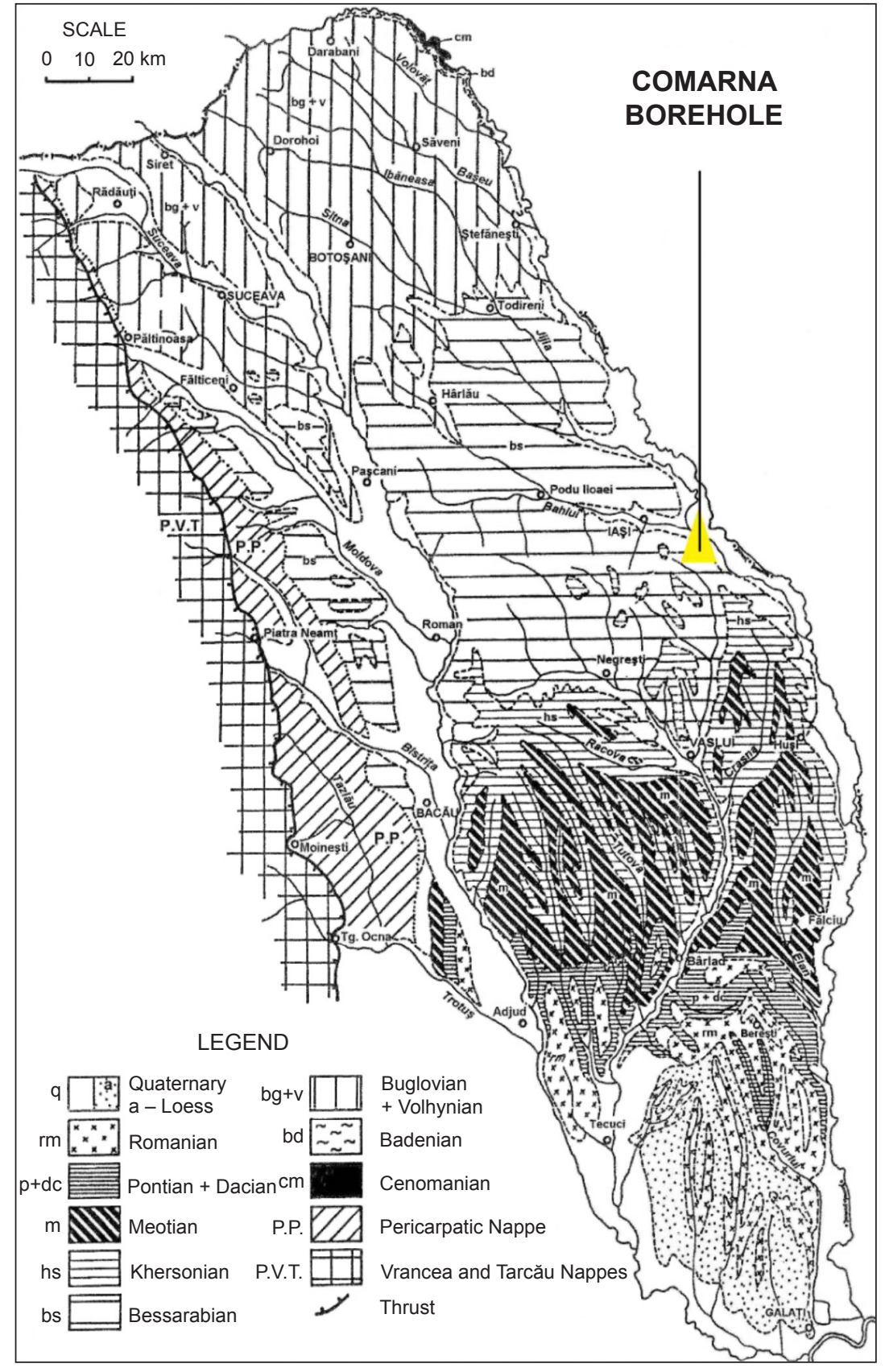

Fig. 1. Location of the Comarna borehole (map taken from Ionesi et al., 2005)

\section{GEOLOGY OF THE STUDIED AREA}

The Moldavian Platform represents the southwestern part of the East European Platform. On the territory of Romania, it has an extension between the Oriental Carpathians and the Prut River (L. Ionesi et al., 2005; V. Mutihac, G. Mutihac, 2010), being limited by the Pericarpic Fault in the west, the Fălciu-Plopana Fault in the south, and by the state border in the east and in the north (L. Ionesi, 1994; Brânzilă, 2003).
The Sarmatian is part of the Sedimentary Cover and outcrops on the entire Moldavian Platform, being composed of four substages: Buglovian, Volhynian, Bessarabian, and Khersonian (L. Ionesi, 1994).

The Buglovian (sensu Laskarev) outcrops only in the northern platform, consisting predominantly of clays, tuffs, sands, conglomerates and limestones, and from the faunistic point of view it is represented by associations of bivalves, gastropods, foraminifera, ostracods, 
bryozoans etc. (L. Ionesi and B. Ionesi, 1982; Brânzilă, 2003).

The Volhynian is open in several localities from the northern Moldavian Platform (L. Ionesi, 1994) and consists predominantly of clays, silts, sands, sandstones, limestones, rudites and arenites. The characteristic fauna of this substage is represented by bivalves, gastropods and foraminifera (Brânzilă, 2003).

The Bessarabian is open from the BaiaSanta Mare line in the south till Vaslui (L. Ionesi, 1994; Brânzilă, 2003), consisting mainly of clays, sands, gravels, limestones and characterized, from the faunistic point of view, by molluscs, foraminifera, and vertebrate remains (Brânzilă, 2003).

\section{MATERIALS AND METHODS}

The ten fossiliferous samples were collected for micropaleontological analyses: three at the $\mathrm{Bu}-$ glovian level, three from Volhynian deposits and four belonging to Bessarabian (Fig. 2).

These samples were processed at the Geology and Palaeontology Laboratory of the Faculty of Geography and Geology in accordance with the micropaleontology-specific methods.

The photographing of foraminifera taxa was carried out with the electron microscope of the Faculty of Biology of "Alexandru Ioan Cuza" University.

\section{IDENTIFIED MICROFAUNA}

The foraminifera association identified at the $\mathrm{Bu}-$ glovian level (Table) consists of miliolids (Quinqueloculina, Cycloforina, Varidentella, Nodobaculariella and Articulina genera), elphidiids (Elphidium and Porosononion genera), nonionids (Nonion genus), and cibicidids (Cibicides and Lobatula genera). Miliolids have a high abundance in sample 1, and the Elphidium genus has a significant abundance at the level of sample 3.

The foraminifera index-species specific of the Buglovian substage are Lobatula lobatula (W. et J.) (Cibicides lobatulus W. et J.), Cycloforina karreri ovata (Serova) (Quinqueloculina karreri ovata Serova) and Cycloforina fluviata

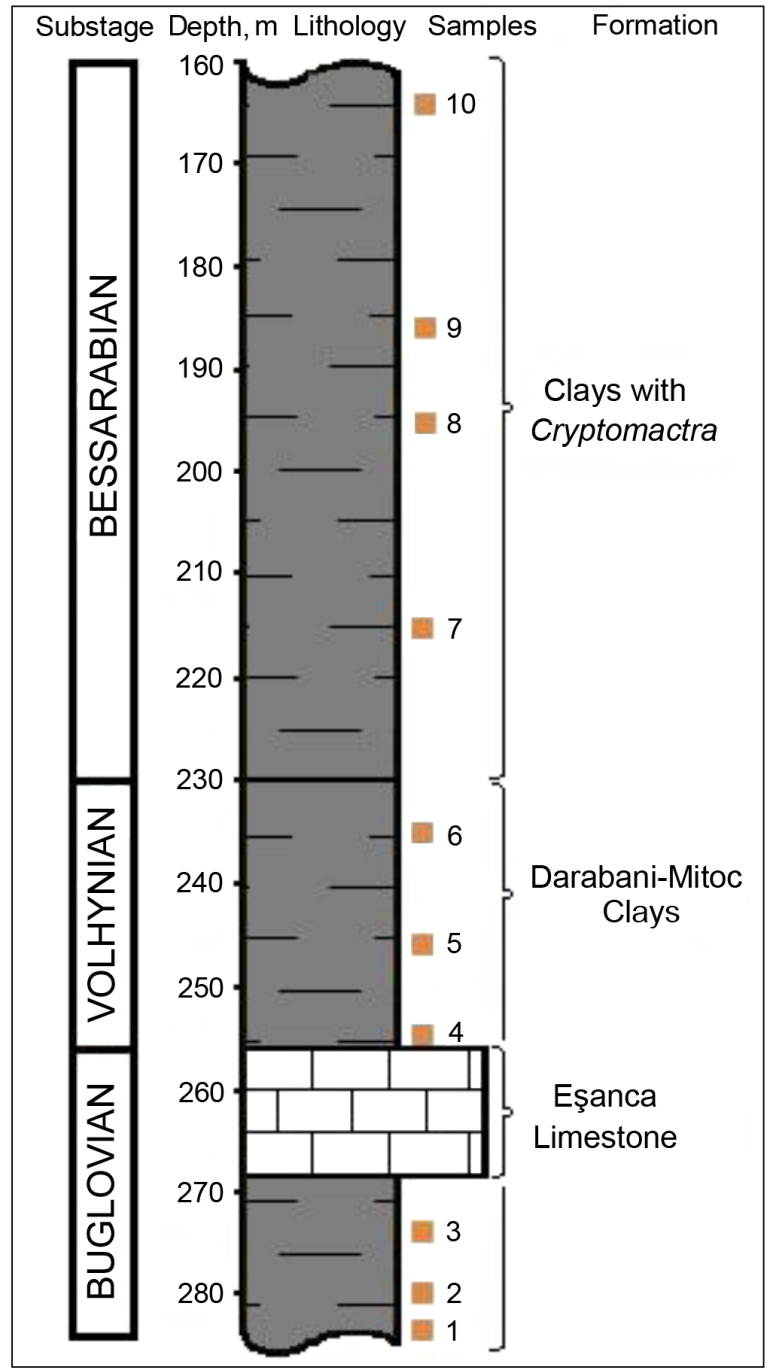

Fig. 2. The lithological column of the Comarna drilling

(Vengl.) (Q. fluviata Vengl.) (B. Ionesi, 1991), but although are present in the association, they are low in frequency.

The analysed Buglovian samples also revealed a significant number of ostracods and otoliths.

The Volhynian analysed in samples 4, 5 and 6 (Table) is characterized by a foraminifera association in which the miliolids (Quinqueloculina, Articulina and Cycloforina genera), the elphidiids (Porosononion genus) and the nonionids (Nonion genus) are significantly abundant. Within this association, the presence of ostracods was also signalled.

A microfauna of foraminifera characterized by a generally low frequency resulted from 
Table. The microfaunal association identified in the Sarmatian deposits from the core samples of the Comarna borehole. Taxa 1-34 denote foraminifera species (Plates I, II, and III)

\begin{tabular}{|c|c|c|c|c|c|c|c|c|c|c|c|}
\hline \multirow{2}{*}{$\begin{array}{l}\text { Criterion } \\
\text { Number }\end{array}$} & \multirow{2}{*}{$\begin{array}{c}\text { Substages } \\
\text { Species/Samples }\end{array}$} & \multicolumn{3}{|c|}{ Buglovian } & \multicolumn{3}{|c|}{ Volhynian } & \multicolumn{4}{|c|}{ Bessarabian } \\
\hline & & 1 & 2 & 3 & 4 & 5 & 6 & 7 & 8 & 9 & 10 \\
\hline 1 & Articulina problema BOGD. & 1 & & 1 & & & 10 & & & 1 & 1 \\
\hline 2 & Articulina sarmatica (KARRER) & 1 & 1 & & & & & & & & \\
\hline 3 & Cibicides badenensis (d'ORB.) & & & 9 & & & & & & & \\
\hline 4 & Cycloforina fluviata (VENGL.) & 2 & & & & 3 & & & & & \\
\hline 5 & Cycloforina karreri ovata (SEROVA) & & 1 & & & & & & & & \\
\hline 6 & Cycloforina toreuma (SEROVA) & & 2 & & & & & & & & \\
\hline 7 & Elphidium aculeatum (d'ORB.) & & & 8 & & & & 2 & & & \\
\hline 8 & Elphidium flexuosum (d'ORB.) & & & 5 & & & & & & & \\
\hline 9 & Elphidium hauerinum (d'ORB.) & 4 & & & & & & & & & \\
\hline 10 & Elphidium listeri (d'ORB.) & & & 2 & & & & & & & \\
\hline 11 & Elphidium macellum (F. et M.) & & & & & & & & & & 1 \\
\hline 12 & Elphidium macellum tumidocamerale BOGD. & & & 11 & & & & & & & 1 \\
\hline 13 & Elphidium rugosum (d'ORB.) & & & & & & & & & & 1 \\
\hline 14 & Elphidium subumbilicatum CZJZEK & & 5 & & & & & & & & \\
\hline 15 & Elphidium sp. & 3 & & & & & & & & 1 & \\
\hline 16 & Lobatula lobatula (W. et J.) & & & 5 & & & & & & & \\
\hline 17 & Nodobaculariella ovalis VENGL. & & & 1 & & & & & & & \\
\hline 18 & Nonion bogdanowiczi VOLOSH. & 4 & 2 & & 26 & 1 & 2 & & & 1 & 2 \\
\hline 19 & Nonion sp. & & & & 26 & & 2 & & & 1 & \\
\hline 20 & Porosononion martkobi (BOGD.) & 3 & & & & & & & & & \\
\hline 21 & Porosononion subgranosus (EGGER) & 1 & 2 & & 4 & 79 & 1 & & & 1 & 4 \\
\hline 22 & Porosononion subgranosus ssp. & & & & & & & & & 1 & 8 \\
\hline 23 & Porosononion subgranosus umboelata GERKE & & 1 & & & & & & & 1 & 2 \\
\hline 24 & Quinqueloculina akneriana d'ORB. & 1 & 2 & & & 1 & & & & & \\
\hline 25 & Quinqueloculina akneriana argunica GERKE & 3 & & & & & 3 & & & & \\
\hline 26 & Quinqueloculina akneriana longa GERKE & 7 & & & 1 & & 3 & & & & \\
\hline 27 & Quinqueloculina gracilis KARRER & & & & & 1 & & & & & \\
\hline 28 & Quinqueloculina karreri REUSS & 1 & & & & & & & & & \\
\hline 29 & Quinqueloculina pseudoangustissima KRASH. & & & & & & 3 & & & & \\
\hline 30 & Quinqueloculina reussi BOGD. & 2 & & & & & & & & & \\
\hline 31 & Quinqueloculina reussi virgata SEROVA & 4 & & & 1 & & & 1 & & & \\
\hline 32 & Quinqueloculina sp. & 15 & & & & 59 & 43 & & & & 1 \\
\hline 33 & Turborotalia bykovar AISENSTAT & & & & & & & & & 1 & \\
\hline 34 & Varidentella georgiana ŁUCK. & & 4 & & & & & & & & \\
\hline 35 & Bivalvia sp. & & & & & & & & & 1 & \\
\hline 36 & Gastropoda sp. & & & & & & & & & & 1 \\
\hline 37 & Ostracoda sp. & 7 & 12 & 34 & & 3 & & & & & \\
\hline 38 & Otoliths & 2 & & & & & & 66 & 5 & & 1 \\
\hline
\end{tabular}




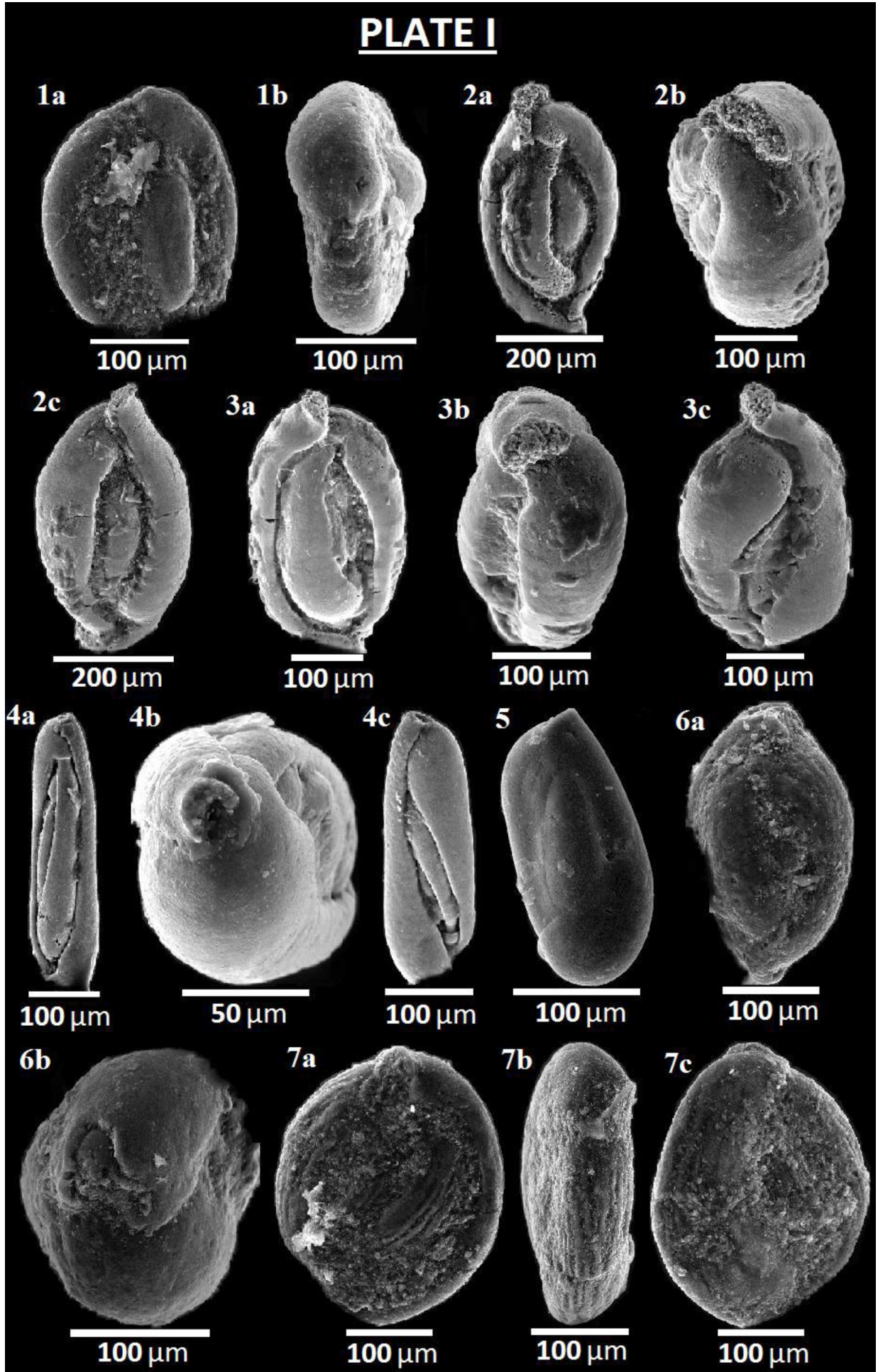

PLATE I: 1 a,b - Quinqueloculina akneriana akneriana d'Orbigny, 1846 - sample 2; 2 a,b,c - Quinqueloculina akneriana argunica Gerke, 1938 - sample 6; 3 a,b,c - Quinqueloculina akneriana longa Gerke, 1938 - sample 6; 4 a,b,c - Quinqueloculina pseudoangustissima Krasheninnikov, 1959 - sample 6; 5 - Quinqueloculina reussi virgata Serova, 1955 - sample 7; 6 a,b - Cycloforina karreri ovata (Serova, 1955) - sample 2; 7 a,b,c - Cycloforina toreuma (Serova, 1955) - sample 2 


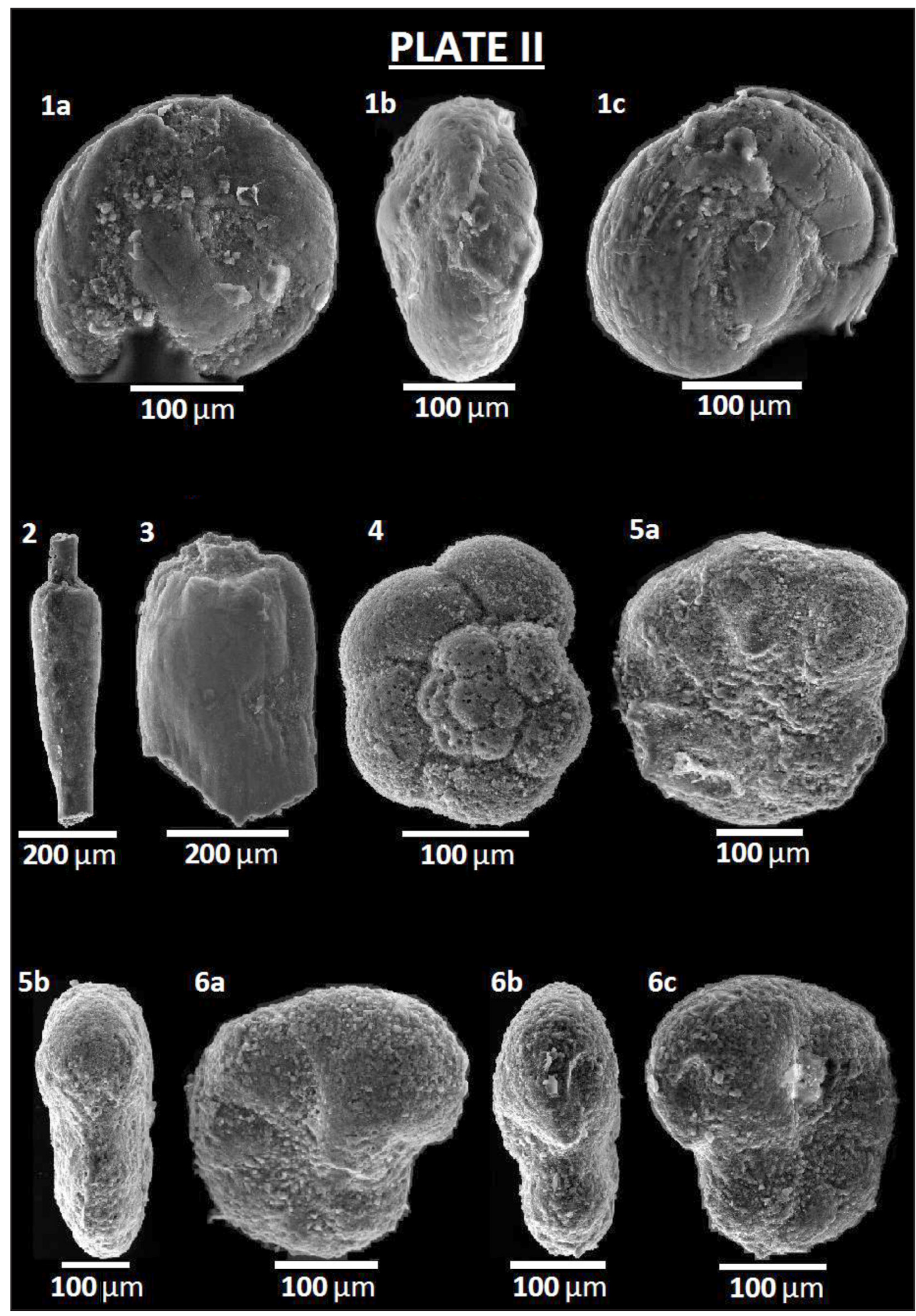

PLATE II: 1 a,b,c - Varidentella georgiana Łuczkowska, 1974 - sample 2; 2 - Articulina problema Bogdanowicz, 1952 - sample 6; 3 - Articulina sarmatica (Karrer, 1877) - sample 2; 4 - Turborotalia bykovae Aisenstat, 1960 - sample 9; 5 a,b - Cibicides badenensis (d'Orbigny, 1846) - sample 3; 6 a,b,c - Lobatula lobatula (Walker et Jacob, 1798) - sample 3 


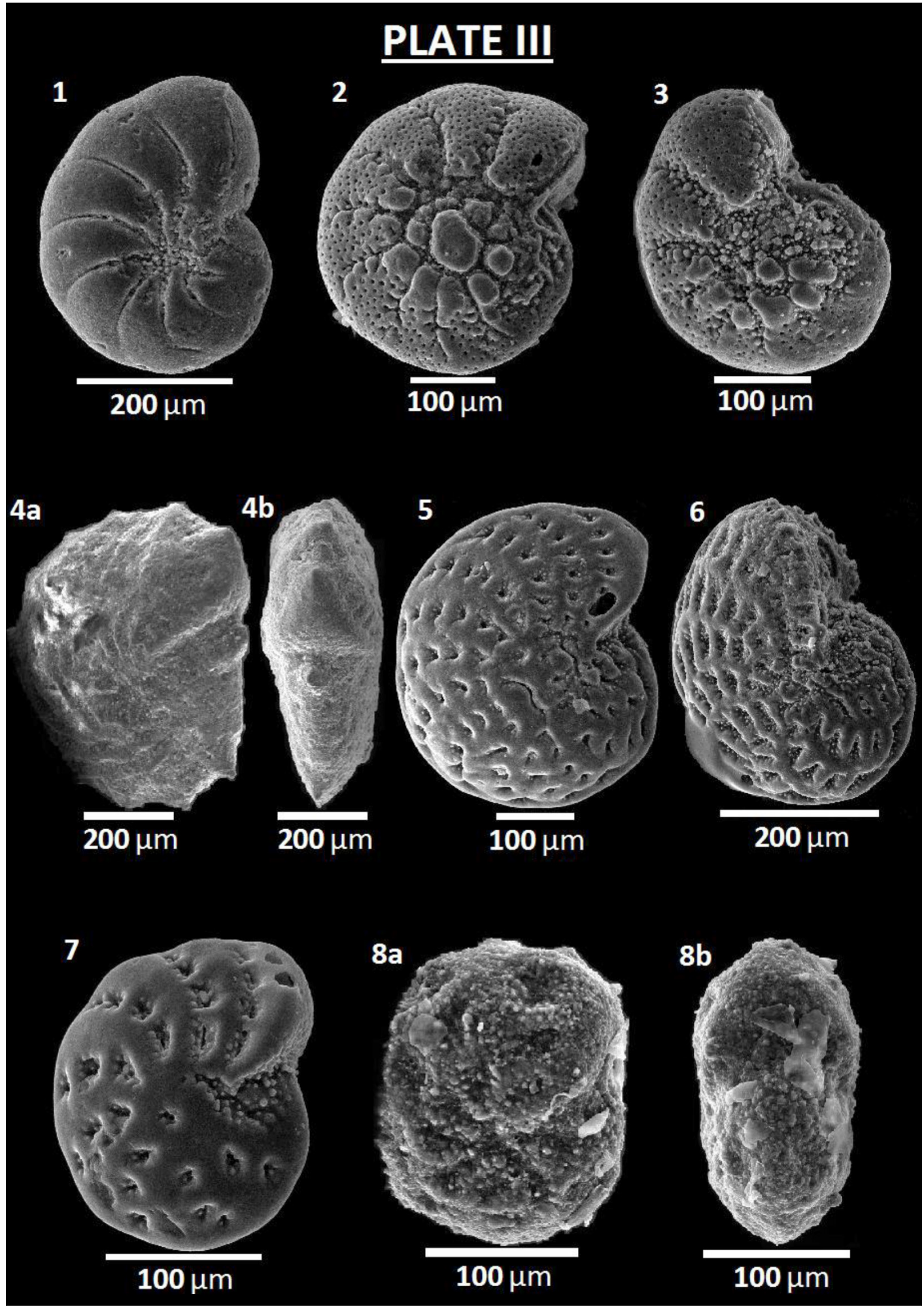

PLATE III: 1 - Nonion bogdanowiczi Voloshinova, 1952 - sample 2; 2 - Porosononion subgranosus (Egger, 1857) - sample 10; 3 - Porosononion subgranosus umboelata Gerke, 1960 - sample 10; 4 a,b - Elphidium aculeatum (d'Orbigny, 1846) - sample 3; 5 - Elphidium macellum (Fichtel et Moll, 1798) - sample 10; 6 - Elphidium macellum tumidocamerale Bogdanowicz, 1932 - sample 10; 7 - Elphidium rugosum (d'Orbigny, 1846) - sample 10; 8 a,b - Elphidium subumbilicatum Czjzek, 1848 - sample 2 
the analysis of the Bessarabian samples (Table). The elphidiids (Porosononion and Elphidium genera) have a greater weight within the identified association. The miliolids (Quinqueloculina and Articulina genera), the nonionids (Nonion genus) and the globorotaliids (Turborotalia genus) have a low frequency. Noteworthy is the presence of a significant number of otoliths in the Bessarabian microfaunal association, especially at the level of sample 7 .

\section{SIGNIFICANCE OF ANALYSED MICRO- FAUNA}

The foraminifera microfauna identified in the $\mathrm{Bu}$ glovian deposits at the level of the first three samples taken from the core samples of the Comarna drilling presents a wide variety of species and a high abundance of individuals, which suggests optimum conditions of living and food.

There is a predominance of euryhaline forms of miliolids and elphidiids. The Badenian stenohaline forms, such as Bulimina, Bolivina (Popov et al., 2004) and Velapertina (Popescu, 1995; Ispas, 2016; 2017), are missing, which means that a transition from a normal salinity marine regime to a brackish regime took place at the beginning of the Sarmatian. Although the planktonic forms are missing, the abundance of benthic calcareous forms shows a normal oxygen content in the warm water of the sea. The miliolids and the Elphidium genus, suggest a marine shelf environment.

The Volhynian deposits have varied foraminifera microfauna and a high abundance of individuals, which proves normal living conditions. There is a predominance of euryhaline forms of miliolids, nonionids, and Porosononion genus, which justifies a brackish regime and a marine shelf environment with warm and still waters.

At the level of Bessarabian deposits, the identified foraminifera association presents a moderate variety of species and a low abundance of individuals. The elfidiids (especially Porosononion genus), which are forms adapted generally to the sandy, hard and even muddy substrate (Brânzilă, 1999), have a significant weight in this foraminifera association. The Bessarabian microfauna includes otoliths, which attests to a normal regime of oxygenation of the sea water, as well as optimal conditions of life and food.

\section{CONCLUSIONS}

The Lower Sarmatian is characterized by varied and abundant foraminifera microfauna. Due to a sudden change of the marine regime with normal salinity to a brackish regime of the Paratethys waters, stenohaline forms specific to the Upper Badenian are replaced by the euryhaline forms. Foraminifera species that indicate the beginning of the Sarmatian on the Moldavian Platform are Lobatula lobatula (W. et J.), Cycloforina karreri ovata (Serova) and Cyclophorina fluviata (Vengl.), but they are low in frequency.

The predominant foraminifera are miliolids, elphidiids, nonionids, and benthic calcareous forms, suggesting a marine shelf environment with warm, still waters, optimal oxygenation regime, and normal living conditions (B. Ionesi, 1968; Ispas, 2016).

The Cibicides genus, although present in low quantities and small size, indicates a sudden modification of the marine regime at the beginning of the Sarmatian (Paghida-Trelea, 1969).

\section{ACKNOWLEDGEMENTS}

The author wishes to thank Professor Dr. Mihai Brânzilă both for his theoretical and practical support and for granting the material for micropaleontological analyses from the drilling executed in Comarna, and to Conferrer Dr. Viorel Ionesi, for theoretical and practical support.

Received 12 June 2017 Accepted 8 September 2017

\section{References}

1. Brânzilă M. Geologia părții sudice a Câmpiei Moldovei. Iași: Corson; 1999. 221 p., 33 pl. Romanian.

2. Brânzilă M. Geologia României. Iași: Univ. "Al. I. Cuza"; 2003. Romanian. 
3. Brânzilă M. Foraminifera assemblages of the backbulge depozone from the Moldavian Platform - the Basarabian. Acta Palaeontologica Romaniae. 2004; 4: 45-54.

4. Brânzilă $\mathrm{M}$, Țabără $\mathrm{D}$. The palynological content of Lower Basarabian (The clays with Cryptomactra) on the Moldavian Platform. Analele Ştiințifice ale Universităţii “Al. I. Cuza” Iaşi, Geol., T. XLIX - L (2003-2004), 2005; 277-91.

5. Grasu C, Brânzilă M, Crina M, Boboş I. Sarmațianul bazinelor de foreland ale Carpaților Orientali. Bucureşti: Ed. Tehnică; 2002. Romanian.

6. Ionesi B. Stratigrafia depozitelor miocene de platformă dintre valea Siretului și valea Moldovei. București: Ed. Acad. Rom;1968. 391 p. Romanian.

7. Ionesi B. Biozonation du Sarmatien de la Plate-forme Moldave. Comun. ses. șt. Univ. “Al. I. Cuza” Iași 25-20/X, 1991. In L. Ionesi (1995) Rom J Stratig. 76/2. p. 7, București. Romanian.

8. Ionesi L. Geologia unităților de platformă și a Orogenului Nord - Dobrogean. București: Editura Tehnică; 1994. Romanian.

9. Ionesi L, Ionesi B. Contribution a l'etude du Bouglovien d’entre Başeu et Prut. An. Șt. Univ. Iași, T. XXVIII, s. II b, Geol.-Geogr. 1982. French.

10. Ionesi L, Ionesi B, Lungu A, Roşca V, Ionesi V. Sarmaţianul mediu şi superior de pe Platforma Moldovenească. Bucureşti: Ed. Academiei Române; 2005. 558 p. Romanian.

11. Ispas B-A. Reconstituirea paleomediilor de sedimentare la limita Badenian/Sarmaţian, din nord-estul Platformei Moldovenești, pe baza faunei de foraminifere. Teză de doctorat. Univ. “Al. I. Cuza” Iași. 2016.

12. Ispas B-A. New genera of foraminifera identified for the upper Badenian deposits to the North-Eastern part of the Moldavian Platform. Journal of Earth Science and Engineering 7. 2017; 20-7. doi: 10.17265/2159$581 \times 2017.01 .003$.

13. Mutihac V, Mutihac G. Geologia României în contextul geostructural central - est - euro- pean. București: Ed. Didactică și Pedagogică; 2010. Romanian.

14. Paghida-Trelea N. Microfauna Miocenului dintre Siret și Prut. București: Ed. Acad. Rom; 1969. 189 p., 14 pl.

15. Popescu Gh. Contribution to the knowledge of the Sarmatian foraminifera of Romania. Rom J Paleontology. 1995; 76: 85-98.

16. Popov SV, Rögl F, Rozanov AY, Steininger FF, Shcherba IG, Kováč M. Lithological-paleogeographic maps of Paratethys. Courier Forschungsinstitut Senckenberg. 2004; 250: 46 p.

17. T,abără D, Chirilă G. Palaeoclimatic estimation from Miocene of Romania, based on palynological data. Carpathian Journal of Earth and Environmental Sciences. 2012a; 7(2): 195-208.

18. T,abără D, Chirilă G. The evolution of the Sarmatian palaeoclimate in North-Eastern Romania: a palaeobotanical approach. Analele Științifice ale Universității “Al. I. Cuza” din Iași, seria Geologie. 2012b; 58(1): 5-21.

\section{Bogdan-Adrian Ispas}

\section{FORAMINIFERAIS PAGRĮSTA RYTŲ MOLDA- VIJOS PLATFORMOS SARMATIJOS PERIODO (PLAČIĄJA PRASME) TELKINIŲ BIOSTRATI- GRAFIJA IR PALEOAPLINKA}

\section{Santrauka}

Šis tyrimas pagrịstas mikropaleontologiniais tyrimais, atliktais Rytų Moldavijos platformos Sarmatijos periodo (plačiaja prasme) telkiniuose. Lobatula lobatula (W. et J.), Cibicides lobatulus (W. et J.), Cycloforina karreri ovata (Serova), Quinqueloculina karreri ovata (Serova), Cycloforina fluviata (Vengl.), Q. fluviata (Vengl.) foraminiferų rūšys, žyminčios Sarmatijos periodo pradžią Moldavijos platformoje, taip pat kitos gentys, tokios kaip Nonion, Elphidium, Articulina, rodo, kad gręžinio viršutinès Badeno periodo dalies specifinè mikrofauna prisitaikè prie Paratetijos jūros mažesnio druskingumo vandens.

Raktažodžiai: foraminifera, biostratigrafija, paleoekologija, Sarmatijos periodas (plačiąja prasme), miocenas, Moldavijos platforma 